\title{
Knowledge and Attitude of Newly Graduated Doctors towards Soil Transmitted Helminthic Infections- Sudan-2017
}

\author{
Hafiz A ${ }^{1 *}$, Mustafa $\mathrm{K}^{2}$ and Daffa Alam ${ }^{3}$ \\ ${ }^{1}$ MPH Candidate, Sudan \\ ${ }^{2}$ Professor of Preventive Medicine \& Epidemiology, Department of Medicine, \\ Alneelain University, Khartoum, Sudan \\ ${ }^{3}$ Doctor of Preventive Medicine \& Epidemiology, Department of Medicine, Sudan \\ Academic Health
}

\begin{tabular}{c} 
Review Article \\
Volume 2 Issue 1 \\
Received Date: November 01, 2017 \\
Published Date: May 25, 2018 \\
DoI: $10.23880 /$ phoa-16000123 \\
\hline
\end{tabular}

*Corresponding author: Hafiz Eed, MPH Candidate, Sudan, E-mail: hafizeed@gmail.com

\section{Abstract}

Introduction: The main soil transmitted nematode species are Ascaris lumbricoides, Trichuris trichiura and the hookworms (Necator americanus and Ancylostoma duodenal). Medical students and residents interest in global health has been growing rapidly. Meanwhile, educational opportunities for trainees remain limited, and many trainees participate in global health experiences abroad without adequate preparation.

Research Methodology: This was institutional-based cross sectional study concerning knowledge and attitude of the soil transmitted helminthes among (218) newly graduated doctors with $100 \%$ response rate. The data were collected in December 2016 using standardized self-administered questionnaire composed 36 close-ended questions Data were analyzed using Statistical Package for Social Science (SPSS) version 20. Univariate analysis for all determinants, bivariate analysis was carried by cross tabulation.

Results: There were statistically significant differences between type of curriculum $51.8 \%$ traditional with the main intervention strategy to control the spread of the helminthes (P-value $=0.000)$. Also, significant difference $(\mathrm{P}$-value $=$ 0.000), between type of curriculum and drug of choice of an adult patient with Ascariasis. And type of curriculum with primary prevention for Ancylostoma duodenal significant different was (P-value $=0.000$ ).

Conclusion: Participants from medical colleges in Sudan seems to be studied in theoretically $81.2 \%$, and $51.8 \%$ of participants studying on traditional curriculum and the level of their knowledge regarding soil transmitted helminthes was negative in terms of treatment, prevention and control.

Keywords: Soil transmitted nematode species; Soil transmitted helminthes; Newly graduated doctors; Univariate analysis; Ascariasis 
Abbreviations: STH: Soil Transmitted Helminthes; CPD: Continuous Professional Development Center; IDA: Iron Deficiency Anemia.

\section{Introduction}

Parasite helminthes (worms) that infect humans belong to two phyla, phylum Platyhelminthes (flat worms) and phylum nematode (round worms). The main soil transmitted nematode species are Ascaris lumbricoides, Trichuris trichiura and the hookworms (Necatoramericanus and Ancylostoma duodenal) [1,2].

In the vast majority of developing tropical and subtropical regions of the world, helminthes parasite infections, particularly those soil transmitted helminthes and schistosomes, constitute to be major public health and developmental challenges. They are associated with poverty and underdevelopment is most prevalent in the poorest communities of the developing world [3].

Intestinal helminthic infections often lead to iron deficiency anemia (IDA), protein-energy malnutrition, stunting (a measure of chronic under nutrition), wasting (a measure of acute under nutrition), listlessness and abdominal pain and may negatively affect classattentiveness of school children. The tropical climate and poor hygienic conditions under which the socioeconomically deprived rural dwellers live facilitate the development and transmission of these helminthes infections $[4,5]$.

The burden of these helminthes parasite infections has been consistently underestimated in the past, but there was now a general consensus that STH infections and schistosomiasis represent an important public health problem especially for children. Although light helminthic infections are often asymptomatic, the adverse health and nutritional impacts of severe worm infections on children. Without chemotherapeutic treatment, the infections may also have more serious medical consequences in a minority of cases: roundworm infections sometimes lead to fatal intestinal obstruction, hookworm infection can cause severe anemia, and whipworm is associated with chronic dysentery [6,7].

\section{Research Methodology}

This was institutional-based descriptive cross sectional study design. Concerning knowledge and attitude of the soil transmitted helminthes among (218) newly graduated doctors with $100 \%$ response rate. The data were collected in December 2016.

\section{Results}

\begin{tabular}{|c|c|c|c|}
\hline \multicolumn{2}{|c|}{ Characteristics } & Frequency & Percentage \\
\hline \multirow{4}{*}{ Gender } & Male & 46 & 21.1 \\
\cline { 2 - 4 } & Female & 172 & 78.9 \\
\cline { 2 - 4 } & Total & 218 & 100 \\
\cline { 2 - 4 } & 2015 & 32 & 14.7 \\
\cline { 2 - 4 } & 2016 & 186 & 85.3 \\
\cline { 2 - 4 } & Total & 218 & 100 \\
\hline \multirow{3}{*}{ Duraduation date } & 5 years & 19 & 90.4 \\
\cline { 2 - 4 } & 6 years & 197 & 0.9 \\
\cline { 2 - 4 } & 7 years & 218 & 100 \\
\cline { 2 - 4 } & Total & 113 & 51.8 \\
\hline \multirow{3}{*}{ Type of curriculum } & Traditional & 21 & 6.6 \\
\cline { 2 - 4 } & Innovative & 15 & 31.7 \\
\cline { 2 - 4 } & Hybrid & 69 & 100 \\
\cline { 2 - 4 } & I don't know & 218 & 99.1 \\
\cline { 2 - 4 } & Total & 216 & 0.9 \\
\hline \multirow{3}{*}{ Country of graduation } & Sudan & 218 & 100 \\
\cline { 2 - 4 } & Arabic & & \\
\cline { 2 - 4 } & Total & & \\
\hline
\end{tabular}

Table 1: Background characteristics of the study participants. 
About $21.1 \%$ of the participants were males while $78.9 \%$, of them were females with 1:4 males to females' ratio. $90.4 \%$ of the participants studied six years in their medical schools. $51.8 \%$ of the participants were graduated from medical schools adopting traditional curricula while $31.7 \%$ of them reported that they did not know the type of their currciulula. $99 \%$ of the participants were graduated from Sudan.

\begin{tabular}{|c|c|c|c|c|c|c|c|}
\hline \multirow{2}{*}{\multicolumn{3}{|c|}{ Type of curriculum }} & \multicolumn{4}{|c|}{$\begin{array}{c}\text { Intervention strategy to control the spread of the } \\
\text { helminthes in a high-risk group }\end{array}$} & \multirow{3}{*}{ Total } \\
\hline & & & \multirow{2}{*}{$\begin{array}{c}\begin{array}{c}\text { Child } \\
\text { nutrition }\end{array} \\
24 \\
\end{array}$} & \multirow{2}{*}{$\begin{array}{c}\begin{array}{c}\text { Selective mass } \\
\text { chemotherapy }\end{array} \\
73 \\
\end{array}$} & \multirow{2}{*}{\begin{tabular}{|c|}
$\begin{array}{c}\text { Treatment for } \\
\text { individual }\end{array}$ \\
9 \\
\end{tabular}} & \multirow{2}{*}{$\begin{array}{c}\begin{array}{l}\text { I don't } \\
\text { know. }\end{array} \\
113 \\
\end{array}$} & \\
\hline & Count & 7 & & & & & \\
\hline Traditional & $\begin{array}{l}\text { Expected } \\
\text { Count }\end{array}$ & 11.9 & 31.1 & 64.8 & 5.2 & 113 & \\
\hline \multirow[b]{2}{*}{ Innovative } & Count & 5 & 11 & 4 & 1 & 21 & \\
\hline & $\begin{array}{l}\text { Expected } \\
\text { Count }\end{array}$ & 2.2 & 5.8 & 12 & 1 & 21 & \\
\hline \multirow[b]{2}{*}{ Hybrid } & Count & 1 & 9 & 5 & 0 & 15 & \\
\hline & $\begin{array}{l}\text { Expected } \\
\text { Count }\end{array}$ & 1.6 & 4.1 & 8.6 & 0.7 & 15 & \\
\hline \multirow[b]{2}{*}{ I don't know } & Count & 10 & 16 & 43 & 0 & 69 & \\
\hline & $\begin{array}{l}\text { Expected } \\
\text { Count }\end{array}$ & 7.3 & 19 & 39.6 & 3.2 & 69 & \\
\hline \multirow{2}{*}{\multicolumn{2}{|c|}{ Total }} & Count & 23 & 60 & 125 & 10 & 218 \\
\hline & & $\begin{array}{c}\text { Expected } \\
\text { Count }\end{array}$ & 23 & 60 & 125 & 10 & 218 \\
\hline
\end{tabular}

$P$ value $=0.000$

Type of curriculum versus main intervention strategy to control the spread of the helminthes in a high-risk group, yielded statistically significant difference.

Table 2: Type of curriculum versus intervention strategy to control the spread of the helminthes.

\begin{tabular}{|c|c|c|c|c|c|c|c|}
\hline & & & \multicolumn{4}{|c|}{ Drug of choice of an adult patient with Ascariasis } & \multirow{3}{*}{ Total } \\
\hline \multicolumn{3}{|c|}{ Type of curriculum } & Levamisole & Doxycycline & Praziquantel & I don't know & \\
\hline \multirow{2}{*}{ Traditional } & Count & 42 & 0 & 62 & 9 & 113 & \\
\hline & Expected Count & 34.2 & 13 & 42.5 & 23.3 & 113 & \\
\hline \multirow{2}{*}{ Innovative } & Count & 3 & 3 & 13 & 2 & 21 & \\
\hline & Expected Count & 6.4 & 2.4 & 7.9 & 4.3 & 21 & \\
\hline \multirow{2}{*}{ Hybrid } & Count & 12 & 0 & 3 & 0 & 15 & \\
\hline & Expected Count & 4.5 & 1.7 & 5.6 & 3.1 & 15 & \\
\hline \multirow{2}{*}{ I don't know } & Count & 9 & 22 & 4 & 34 & 69 & \\
\hline & Expected Count & 20.9 & 7.9 & 26 & 14.2 & 69 & \\
\hline \multirow{2}{*}{\multicolumn{2}{|c|}{ Total }} & Count & 66 & 25 & 82 & 45 & 218 \\
\hline & & Expected Count & 66 & 25 & 82 & 45 & 218 \\
\hline
\end{tabular}

$P$ value $=0.00$

Type of curriculum versus knowledge of participants about drug of choice of an adult patient with Ascariasis yielded statistically significant difference (P value $=0.00$ ).

Table 3: Type of curriculum versus knowledge of participants about drug of choice of an adult patient with Ascariasis. 


\begin{tabular}{|c|c|c|c|c|c|c|}
\hline \multirow{2}{*}{\multicolumn{3}{|c|}{ Type of curriculum }} & \multicolumn{3}{|c|}{ Primary prevention for Ancylostoma doudenale } & \multirow{3}{*}{ Total } \\
\hline & & & \multirow{2}{*}{$\begin{array}{c}\text { Shoes wearing } \\
61\end{array}$} & \multirow{2}{*}{$\begin{array}{c}\begin{array}{c}\text { Avoiding of } \\
\text { swimming in } \\
\text { river }\end{array} \\
30 \\
\end{array}$} & \multirow{2}{*}{$\begin{array}{c}\text { I don't know } \\
113\end{array}$} & \\
\hline Thodition & Count & 22 & & & & \\
\hline Iraditional & Expected Count & 22.8 & 44.6 & 45.6 & 113 & \\
\hline \multirow{2}{*}{ Innovative } & \begin{tabular}{|c|} 
Count \\
\end{tabular} & 10 & 2 & 9 & 21 & \\
\hline & Expected Count & 4.2 & 8.3 & 8.5 & 21 & \\
\hline \multirow{2}{*}{ Hybrid } & Count & 6 & 3 & 6 & 15 & \\
\hline & Expected Count & 3 & 5.9 & 6.1 & 15 & \\
\hline \multirow{2}{*}{ I don't know } & Count & 6 & 20 & 43 & 69 & \\
\hline & Expected Count & 13.9 & 27.2 & 27.9 & 69 & \\
\hline \multirow{2}{*}{\multicolumn{2}{|c|}{ Total }} & \begin{tabular}{|c|} 
Count \\
\end{tabular} & 44 & 86 & 88 & 218 \\
\hline & & Expected Count & 44 & 86 & 88 & 218 \\
\hline
\end{tabular}

$P$ value $=0.00$

The type of curriculum versus knowledge of the participants about primary prevention for Ancylostoma doudenale, yielded statistically significant difference (P value $=0.00$ ).

Table 4: Curriculum versus knowledge of participants about primary prevention for Ancylostoma doudenale.

\section{Discussion}

$21.1 \%$ of the study participants were males, while $78.9 \%$, of the participants were females with 1:4 male to female ratio. Sudan HRH Survey revealed that the percentage of the female among the total health workers is $51 \%$. This could be a result of the increasing female Intake to the health training institutes, especially the medical and nursing schools [8].

Only37.6\% of the study participants answered drug of choice of an adult patient with Ascariasis praziguntel tablet $600 \mathrm{mg}$, and $30.3 \%$ of them answered as Levamisole $150 \mathrm{mg}$ tablet. There was statistically significant difference $(\mathrm{P}$-value $=0.00)$, between type of curriculum and drug of choice for treatment of an adult patient with Ascariasis which indicates that curricula studied by the participants were traditional and mostly theoretical [9].

Only $40.8 \%$ of the study participants identified the primary prevention of ancylostomiasis as construction of pit latrines and 28\% identified shoes wearing while $22.9 \%$ said avoiding of swimming in river. There was statistically significant difference (P-value $=0.000)$ between type of curriculum and participants' knowledge of primary prevention for ancylostomiasis. This may reflect the curricular variation in addressing the topic. Nevertheless, only $20.2 \%$ of the participants identified the primary prevention of ancylostomiasis as shoes wearing [10].
About $64.7 \%$ of the study participants identified health education as the main intervention to control the spread of helminthes in a community with high intensity of infection. About 57.5 of the study participants identified treatment of individual cases as the main intervention strategy that can be applied to control the spread of the helminthes in a high-risk group. There was statistically significant difference $(\mathrm{P}$-value $=0.00)$ between the type of curriculum and drug the main intervention strategy that can be applied to control the spread of the helminthes in a high-risk group such as school age children. WHO has recommended three interventions measures to control morbidity due to STH infections. This includes regular drug treatment of high-risk groups for reduction of the worm burden over time, health education and sanitation supported by personal hygiene aimed at reducing soil contamination [11].

$42.7 \%$ of the study participants studied about soil transmitted helminthes in the Parasitology, 38.1\% studied in Epidemiology, and $18.3 \%$ studied in Community Medicine/Preventive Medicine. There was statistically significant difference (P-value $=0.000)$ between type of curriculum and subjects related to soil transmitted helminthes studied by the participants at under graduate level. The study indicates that soil transmitted helminthes is scattered between different subjects without integration and mostly at the pre-clinical level [12]. 


\section{Conclusion}

Participants from medical colleges in Sudan seems to be studied in theoretically $81.2 \%$, and $51.8 \%$ of participants studying on traditional curriculum and the level of their knowledge regarding soil transmitted helminthes was negative in terms of treatment, prevention and control.

\section{References}

1. Kennedy MW, Harnett W (2013) Parasitic nematodes. Wallingford, Oxford shire: CAB International.

2. Simarmata N, Sembiring T, Ali M (2016) Nutritional status of soil-transmitted helminthiasis-infected and uninfected children. Paediatrica Indonesiana 55(3): 136.

3. Parajuli RP, Umezaki M, Watanabe C (2009) Behavioral and nutritional factors and geohelminth infection among two ethnic groups in the Terai region, Nepal. American Journal of Human Biology 21(1): 98-104.

4. Stothard J, Bustinduy A, Montresor A (2014) Preventive chemotherapy for schistosomiasis and soil-transmitted helminthiasis by cotreatment with praziquantel and albendazole. Clinical Investigation 4(2): 163-176.

5. Getnet A, Seble W (2015) The Association Between Major Helminthes Infections (Soil-Transmitted Helminthes and Schistosomiasis) and Anemia Among School Children in Shimbit Elementary School, Bahir Dar, Northwest Ethiopia. American Journal of Health
Research 3(2):97.25. Who w. control and prevention. Geneve: who 3(2): 97-104.

6. Kabala A (2017) Khartoum, capital city of Sudan [Internet]. Visitcapitalcity.com. [cited 30 January 2017].

7. Government of Sudan Federal Ministry of Health Directorate General of Human Resources for Health Development [Internet]. Docplayer.net. 2017 [cited 1 February 2017].

8. Irby DM, Cooke M, O’Brien Bc (2010) Calls for Reform of Medical Education by the Carnegie Foundation for the Advancement of Teaching: 1910 and 2010. Academic Medicine 85(2): 220-227.

9. Rujeni N, Morona D, Ruberanziza E, Mazigo HD (2017) Schistosomiasis and soil-transmitted helminthiasis in Rwanda: an update on their epidemiology and control. Infectious Diseases of Poverty 6(1): 8.

10. Musa BOP, Onyemelukwe GC, Ahmad AA (2008) Reactivity of Antibodies to Hookworm ExcretorySecretory Antigens from Hookworm Infected Patients in Northern Nigeria. International Journal of Infectious Diseases 12(1): 389.

11. Adeyeba OA, Akinlabi AM (2002) Intestinal Parasitic infections among school children in a rural cominunity, Southwest Nigeria: Nig J Parasitol 23: 1118.

12. Stephenson LS, Holland CV, Cooper ES (2000) The public health significance of Trichuristrichiura. Parasitology 121(S1): 73-95. 